\title{
Injection Molding Quality Improvement by Advanced Virtual Simulations
}

Karel Raz, Martin Zahalka, Zdenek Chval

Regional Technological Institue, Faculty of Mechanical Engineering, University of West Bohemia. Univerzitni 8, 30614 Plzen. Czech Republic. E-mail: kraz@rti.zcu.cz, martinza@rti.zcu.cz, zdchval@rti.zcu.cz

Main aim of this article and research is to describe exact influence of key parameter in injection molding process. This key parameter is temperature. Nowadays is possible to use wide range of advanced virtual simulation tools, which were in research used. Article is focused on determining optimal temperature of injected plastic material, temperature of mold and temperature of coolant. For veryfing of virtual method was performed real injection molding with same input parameters and results were compared. For evaluating of achieved quality was investigated influence on whole molding process and influence on final product properties. As testing material was choosen High- Density Polyethylene with properties described in article.

Keywords: Injection Molding, Virtual Simulation, Plastics, Temperature

\section{Acknowledgments}

The present contribution has been prepared under project LO1502 'Development of the Regional Technological Institute' under the auspices of the National Sustainability Programme I of the Ministry of Education of the Czech Republic aimed to support research, experimental development and innovation.

\section{References}

[1] TANG, S. H. (2006). Design and thermal analysis of plastic injection mold, In: Journal of Materials Processing Technology. Switzerland.

[2] ZHENG, R., TANNER, R., FAN, X. (2011). Injection Molding: Integration of Theory and Modeling Methods, Springer-Verlag, Berlin.

[3] BOZZELLI,J. (2010). Understanding Pressure Loss in Injection Molding, In: Plastic Technology.

[4] CRAWFORD, R. J. (2001). Plastic Engineering, Butterworth-Heinemann, Oxford.

[5] HNATKOVA, E., SANETRIK, D., PATA, V., HAUSNEROVA, B., DVORAK, Z., (2016). Mold Surface Analysis after Injection Molding of Highly Filled Polymeric Compounds, In: Manufacturing Technology, Vol. 16, pp. 86-90, ISSN 1213-2489.

[6] COP. J., FOJTL, L., BILEK, O., PATA, V., (2016). Influence of Finishing Operations and Melt Flow Index on Surface Quality of Injection Molded Parts, In: Manufacturing Technology, Vol. 16, pp. 336-338, ISSN 1213-2489.

[7] RUSNAKOVA, S., CAPKA, A., FOJTL, L., ZALUDEK, M., RUSNAK, V., (2016). Technology and Mold Design for Production of Hollow Carbon Composite Parts, In: Manufacturing Technology, Vol. 16, pp. 799-804, ISSN 1213-2489.

[8] FABIAN, M., BOSLAI, R., IZOL. P., JANEKOVA, J., FABIANOVA, J., FEDORKO, G., BOZEK, P., (2015). Use of Parametric 3D Modeling. Tying Parameter Values to Spreadsheets at Designing Molds for Plastic Injection, In: Manufacturing Technology, Vol. 16, pp. 24-31, ISSN 1213-2489.

[9] NHUYEN VO, T., SEIDL, M., (2016). Evaluation of Applicability of Unconventional Cooling Method in Injection Mould, In: Manufacturing Technology, Vol. 16, pp. 220-225, ISSN 1213-2489. 